\title{
Mathematics Teacher Educator Identity: A Conversation Between a Specialist and Generalist
}

\author{
Shaun Murphy \\ University of Saskatchewan \\ Florence Glanfield \\ University of Alberta
}

\begin{abstract}
In this paper, we consider the ways the constructs of being a generalist and specialist in teaching have contributed to our stories to live by in mathematics teacher education. We employ narratives of experience to serve as frames for our discussion in this paper. We explore how our work in public schools contributed to our practice in teacher education and the ways this shapes our curriculum making with preservice teachers. Our stories to live by as mathematics educators highlight how curriculum is more than subject matter objectives and how we are shaped in our relationships with learners.
\end{abstract} inquiry

Keywords: mathematics; generalist; specialist; curriculum; stories to live by; narrative 


\section{Mathematics Teacher Educator Identity: A Conversation Between a Specialist and Generalist}

In this paper we examine our identities, our stories to live by, as mathematics teacher educators by considering the ways we have been shaped as generalist and specialist teachers. We position ourselves as a specialist and generalist intentionally in order to take up the meaning of these identifiers in the context of our work historically and currently. We define a generalist as a teacher who teaches most subjects that a child studies in school. We understand this to apply in particular to elementary teachers. A specialist is a teacher who focuses on one major subject in particular, although may also teach a minor subject. Typically specialists are teachers in secondary schools.

Tensions, in relation to our two stories to live by and their unstable or inadequate ways of framing our teaching practice, emerged as we worked with these two ways of naming ourselves. We use our personal narratives of self and practice as places from which to understand ourselves and our work in teacher education. These narratives helped us frame an understanding of identity as our story to live by-a narrative term conceptualized by Connelly and Clandinin (1999) to "refer to identity, [which] is given meaning by the narrative understandings of knowledge and context” (p. 4) - and enabled us to see how our teaching had unfolded along plotlines given to us in our own teacher education and subsequent work lives. Our understanding is also situated in our personal practical knowledge (Connelly \& Clandinin, 1988), which “allows us to talk about teachers as knowledgeable and knowing people. Personal practical knowledge is understood in relation to a teacher's past experience, in the teacher's present mind and body, and in the future plans and actions. Personal practical knowledge is found in the teacher's practice” (p. 25). We understand our current teacher education practices in relation to our previous practice in classrooms; this takes into account how we understand ourselves as teacher educators who were once grade school teachers. By making the connection between our work in schools and in teacher education programs, we have sought to understand our present work as shaped by our past practice. To this end we sustained an ongoing conversation about the ways we have been shaped by generalist and specialist constructs, and we journeyed between and within the ideas of being a generalist or specialist. These ideas are defined for us in relation to the constructs of generalist and specialist by subject area, practice, and identity. We are shaped by our understanding of the subject matter of mathematics and our current and historical practice as teachers.

\section{Situating Our Work in Narrative Inquiry}

Our inquiry is situated in the narrative work of Clandinin and Connelly (2000). We engaged in this inquiry over 1 year in our work as teacher educators. The narrative commonplaces of temporality, sociality, and spatiality (Connelly \& Clandinin, 2006) are necessary to consider in any narrative inquiry, and in our paper we focus on all three as we consider our shifting narratives of experience across time, in different classrooms, and in relationship with each other and the children, youth, and adults we have worked alongside over our careers.

Connelly and Clandinin (1999) wrote that individuals live storied lives on storied landscapes. Narrative inquiry supported our inquiry into the storied nature of our lives as grade school teachers and as teacher educators on the storied landscapes of schools and universities. In this narrative tradition we could see how we have been shaped over time by our experiences in relation to the constructs of specialist and generalist. When Connelly and Clandinin (2000) are 
asked the question, "Why narrative?” they have responded, “because experience.” Our response to why we would engage in a narrative inquiry about our stories to live by as mathematics teacher educators has the same answer, only more specific, because of our experience.

We began teaching together in a teacher education programme in 2006. Florence was responsible for the secondary and middle years mathematics methods courses, and Shaun taught the elementary mathematics methods courses. Through conversation, we became interested in how we had been shaped by our experiences as grade school teachers and the influence these experiences had on our stories to live by as mathematics teacher educators at a post secondary institution. We decided to begin writing our narratives of experience in relation to our work.

Over the intervening year, we inquired into these narratives in a series of conversations where we made further notes and subsequent alterations to our narratives. These alterations occurred as we attempted to explain in further detail how our current practices had been shaped by our work in grade schools and now by our work in teacher education. Talking about our stories in relation to our practice in mathematics teacher education, we explored how we became mathematics teacher educators. Our unfolding narratives were not without tension. Initially, we told smoother stories of practice that reflected a coherent narrative of identity making in relation to our teaching. However, as the trust built in our relationship, we exposed the places in our narratives where we experienced tensions. When we explored these tensions we saw how they were shaped in relation to our narratives of experience of teaching mathematics teacher education in universities.

When we began our conversations, we saw our past practice clearly defined by specialist or generalist identities. It was only as we talked that we noted these identities, these teaching stories to live by, as constructs given to us. The more we tried to understand ourselves within these constructs, the more we understood they were not identities we could claim. By constructs we mean that the specialist or generalist identities were ways of describing our teaching practice from outside our experience and which in many ways are limiting. It meant for Shaun that, as a generalist, he did not know as much as a specialist, that somehow he was limited in what he could know about a subject matter because he did not have the focused knowledge that someone, like Florence, had in mathematics. Florence, as a specialist, did not have the rich experience Shaun claimed to have that came from knowing children and youth across multiple subject matters over a day. However, as we talked, we saw these understandings as false. Florence had complex relationships with the youth she taught in and out of her subject matter specialty. Shaun had specialized knowledge in subject matters from his practice and use of theoretical literature.

As we wrote and talked, we saw a discrepancy in how our ideas about being a generalist and specialist did not mesh with our practices as teachers. As we wrote above, knowing the children and youth, with whom we worked alongside, was necessary for both of us as we negotiated complex curriculum making (Clandinin \& Connelly, 1992) with them and this necessary way of knowing continues into our current work alongside preservice teachers. Clandinin and Connelly suggested that curriculum “might be viewed as an account of teachers' and children's lives together in schools and classrooms...teacher, learners, subject matter, and milieu are in dynamic interaction” (p. 392). In our current work alongside preservice teachers, we endeavour to open a space to explore the identity making, the ongoing construction of one's story to live by, that is possible in relation to who they are, their experience, and the subject matter of mathematics. 
Our understanding of specialist and generalist constructions is evolving. This is related to our shifts in location from grade schools to higher education teacher education programmes. In this way, we view our current teacher educator identities not as a deliberate act, but as a result of living (Davis, Sumara, \& Luce-Kapler, 2000). Our relationship to the curricular demands of teaching, as a generalist and specialist, shape our practice in teacher education. It is important to unpack what we mean by evolving in relation to our identities. When we use this idea we understand it alongside Dewey's (1997) concept of continuity, "the principle of continuity through renewal applies. With the renewal of physical existence goes, in the case of human beings, the re-creation of beliefs, ideals, hopes, happiness, misery, and practices” (p. 2). Salient to this paper are our beliefs and practices in mathematics teacher education as changing.

Each of us began our careers as a generalist and a specialist in grade schools. Florence, with a history of being a secondary mathematics specialist, moved to higher education and teaches future secondary mathematics specialists and elementary/middle years generalists. Shaun, with a history of being an elementary generalist, became a specialist as a mathematics teacher educator for elementary and middle years preservice teachers, shifting his identity as a generalist. We wonder, alongside each other, about our work and the tensions involved in these identities within the broader identities we hold as teachers and learners.

The narratives that follow were not written in a single sitting. Rather, they are the culmination of our writing and conversations over time. They are in that sense polished to represent the threads that emerged in our research. They have been written and rewritten numerous times in order to try and capture our stories to live by as teachers and as teacher educators. After the narratives, we unpack them. This unpacking is an expression of retelling and is part of the narrative inquiry cycle of living, telling, retelling, and reliving (Clandinin \& Connelly, 2000).

\section{The Generalist: Shaun}

I began my teacher education programme in the early 1980's as an elementary preservice teacher, and the focus then, as it is now, was on being able to teach all the subjects in elementary school. This understanding was born out on the elementary school landscapes where I was expected to teach all the subjects and teach them well. When I left university with my bachelor's degree in education, I had been prepared to teach all subjects. This does not mean I was an expert in all of them, far from it. As I gained experience in schools, I realized being a generalist allowed me to know my children across different subjects. It provided me with the opportunity to work with them over the course of a day, to know them during various times, and to see how they had different strengths in different subjects. As the years passed, the opportunity to know my children well, for 6 hours a day, 5 days a week, 10 months out of a year, allowed me to understand them deeply; I thought this was the special domain of the generalist teacher. Curriculum began to be more than subject matters and it became centred in the experiences of children in school.

Different years saw a focus on different subject matters as I tried to refine my practice. I attended workshops focused on different subject matters. I belonged to various subject specialist councils in my professional teacher association. Some subjects remained less attended to in my teaching life. I constructed a story to live by around being a generalist, but found I was focused on mathematics, language arts, science, and art. Over time, I became more versed in these subjects and found I was shaping an identity in schools as a curriculum leader in these areas. 
However, this all shifted when I took a faculty position in mathematics education in a teacher education programme. I would no longer be seen as a generalist, but a specialist with a subject matter focus. I began to have a story to live by as the "math guy." I found it interesting and amusing at the same time-me, the math guy - while inside I still storied myself as the language arts guy, the science guy, etc. It helped, though, to secretly have a generalist story, while leading a cover story of specialist. It allowed me to talk to my preservice elementary teachers about multiple subject matters. I was able to talk from experience about my teaching day in an elementary school.

The interesting aspect of my new identity is that I began to see myself as a specialist. My research interests began to focus on children's developing stories to live by around their experiences in mathematics. I was invited to sit on various mathematics committees and present at mathematics education conferences. I focused my own learning on teaching mathematics methods and read widely in the subject area of mathematics with attention on mathematics teacher education. However, when I listened to myself in my mathematics methods classes with the preservice teachers, I was frequently referencing other subjects and using them as examples for ways we can understand mathematics. While I remain the math guy, a specialist, I am still grounded in my elementary classroom practice of generalist teaching.

\section{The Specialist: Florence}

My first degree was a Bachelor of Science in mathematics. This attended to my skill and pleasure in the subject. My passion was to be a teacher and I enrolled in an after-degree Bachelor of Education program. There were several students, both with degrees in mathematics and those without, studying to be secondary mathematics teachers. In the mathematics methods classes, I found a community of mathematics educators. During the mathematics methods classes, I noticed that there was a group of us who loved to explore the mathematical ideas further than others. This positioned us as experts in the class.

When I look back on my teaching career, I realize that I had a position of power in my high school mathematics department because I had a degree in mathematics. Many of my mathematics teacher colleagues with specializations in other areas had much more teaching experience than I did; however, when we talked about mathematical ideas, I was the one to see the relationships between concepts. In my teaching, I started to look for the relationships between the units that we were studying so that I could help my students see the wholeness of mathematics. My colleagues would tease me and say it was because of my mathematics background that I searched for this coherence. Coherence also became necessary in the ways I understood the complexity of my students' lives and in order to do this I made efforts to know them outside of school and through their experiences in other subject matters.

My career then led me to a master's degree in administration, yet half of my classes were in mathematics education. I started to work in curriculum development, then implementation, and then student assessment for the province in which I was living. During that time, I was perceived, once again, as an expert in mathematics curriculum development and student assessment. I would have to negotiate meetings where a variety of mathematics educators, from secondary and post secondary, would come together to talk about the mathematics content that should be taught within the secondary school mathematics curriculum. These meetings caused me to think about why we might have high school students study particular mathematical concepts. It was at this time in my life that I truly started to understand the embedded nature of 
mathematics. This was an important shift for me because I had a surface understanding of secondary school mathematics curriculum from my teaching and I was arriving at a deeper understanding of mathematical ideas in relation to learning as I worked with experienced mathematics educators. I name this shift because it highlights the way my teaching practice was informing my understanding of content. My work in curriculum development and student assessment was helping me to see further relationships in mathematics.

These professional experiences led me to my doctoral work in mathematics education and to eventually become a faculty member who teaches mathematics methods courses, confirming my identity as a specialist. I come to my classes with content first and it is through the exploration of the content that I notice how preservice teachers are making sense of their teaching and identities as mathematics educators. I am intrigued by the ways in which preservice teachers begin to see the connectedness of mathematical ideas within school mathematics.

\section{Unpacking the Narratives}

In this next part of the paper we unpack our narratives with reference to curriculum, the contexts of our stories to live by, and our current practices in teacher education. Through unpacking our narratives, we begin the retelling that gives us new possibility for reliving our practices and developing new understanding in mathematics teacher education.

\section{An Understanding of Curriculum}

As teachers, we are positioned within a profession founded on concepts of curriculum. When we began our teaching careers, our understanding of curriculum was subject-specific. There was a curriculum guide for a subject, and as teachers we were expected to cover the objectives detailed in the document. Over time we became aware of the ways these fixed curriculums were shaped by our relational work with children and the milieus in which we were working. However, our relationships with children and our school contexts did not register with us as curriculum; they were something separate that influenced curriculum. We did not see ourselves as curriculum makers in the ways we talked about it at the beginning of this paper, rather as curriculum deliverers. It was in our graduate work that we came to understand curriculum more broadly- as a course of life (Connelly \& Clandinin, 1988), as something composed in relationship.

The interpretation of the curriculum guides, the experiences of the children and youth, our experiences as teachers, the living we brought to our classrooms were all curriculum. Curriculum was a complex, dynamic, and fluid construct. No longer was it the fixed subject matter objectives, written by provincial curriculum writers, in the guides. However, this was a later understanding, following graduate work. The beginnings of our careers were shaped by the need to cover subject matter objectives, as written in the guides. Looking back now we see that they were objectives arrived at outside of the experience of the individual learners with whom we worked. We began, in our early graduate work to examine curriculum through the work of Schwab (1978) who wrote about curriculum commonplaces. These commonplaces include learner, teacher, subject matter, and milieu. When we reflected on our practice as grade school teachers in our graduate programs we saw that none of these commonplaces could be absent if curriculum was present. 


\section{Curriculum in Our Teaching Practice}

Historically, we had located our understanding of curriculum in the subject matters we taught as a generalist and specialist. Over time, however, curriculum, for Shaun, became more than just the specific objectives of subject matter in curriculum guides and he began to see the learning in multiple out of classroom places in school (Clandinin \& Connelly, 1996) such as the playground, hallways, and buses and how this shaped children's lives in school (Murphy, 2004). In this way, he began to experience shifts in ideas of generalist teaching that previously he had only related to the different subject matters. The children with whom he worked helped him understand that teaching was more that delivering subject matter knowledge. Through them, he expanded his understanding of curriculum in relation to the children and his course work in graduate school.

Florence, as a high school mathematics specialist, viewed curriculum as content within a subject matter. She recalls how the structure of the curriculum influenced her teaching. Subject matter objectives were the place she began in order to construct her children's learning. Objectives in subject matter guides came first and youth's learning attended to those objectives. She was interested in how the objectives were related to each other. This does not imply the children were faceless individuals in front of her, but rather they were there to learn mathematics. Her interest in their learning stemmed from their interactions with objectives in the subject matter guide. These interactions were based on Florence's interpretations of the objectives and they provided the framework for the term she spent with these children. Unlike Shaun, she worked with them for bounded increments in a day and only knew some of them peripherally to her class. She had an understanding that they lived complex lives outside of her classroom, but those lives were expected to be held apart from the objectives offered in the guides. Over time Florence developed an understanding of the relationships needed within the milieu of her classroom. To strengthen these relationships she began to attend to youth's out of school lives and how her relationships with them supported their learning, their interpretation of subject matter objectives. This provided her with an opportunity to see the children with whom she worked as more complex learners and not only as consumers of a mathematics curriculum.

We were both constrained by our specialist and generalist practices as grade school teachers in the ways we developed curriculum for the children and youth with whom we worked. Florence was situated in her practice as a mathematics specialist. For Shaun, mathematics was one subject among many. Within his practice, he began to focus more on the mathematics learning of his children, specializing within his generalist practice as seen in his narrative. However, as can be seen in both narratives, Florence and Shaun were attentive to the lives of children and youth, and while they may not have recognized this early in their practice it did influence the way they taught; their work was shaped by many factors beyond specialist or generalist subject matter knowledge.

Our stories to live by, alongside children, youth, and subject matter, are important in the ways we shaped our living as teacher educators. In our conversations as mathematics teacher educators, we considered how the stories we lived by as classroom teachers shaped our current practice in preservice teacher education. As much as we tried to come up with different examples in order to contrast our teaching, similarities were embedded in each example. When either one of us talked about a concept in our mathematics methods classes, we often embedded it in a story of grade school practice in order to illustrate the ways children might take it up in their knowledge making. Furthermore, we also talked about the use of mathematics in the world 
beyond classrooms and the learning across children's experiences in other subject matters attending to the interaction of the curriculum commonplaces of subject matter, learner, teacher and milieu. This led us to understand the complexity in our relationships with our preservice teachers shaped by the curriculum commonplaces (Schwab, 1978).

As we listened to each other, and as we searched for ways to talk about our practice, we realized that we believed each other's statements to be statements we both use in our work with preservice teachers. These examples highlighted the role of relationships, mathematical identity, representations, and communication. There were no examples we could arrive at that illustrated disparate understandings of teaching mathematics. We realized the terms generalist and specialist were constructs given to us and not found within.

Generalist and specialist constructs were more about our actual teaching assignments and the teaching assignments that our preservice teachers will be given in their work lives. Fundamentally, this implies that we came to our identities as specialist and generalist through our own experiences in our preservice teacher education. Shaun came to specialize in mathematics through his work with children and Florence came to a generalist approach in her teaching through her work with youth. Therefore, while specific identities as generalist or specialist were given to us in our teacher education programmes, the application in classrooms, and through our work with children, interrupts this identity formation (Murphy, 2007) and broadens the scope of our practice. We bring this interruption to our work with preservice teachers. In our practice as mathematics teacher educators, we invite our students to be both specialists and generalists. We hope that they will consider the specialized knowledge that they will require for teaching mathematics in the generalist environments they will find themselves, in both elementary and secondary settings.

\section{The Contexts of Our Stories to Live By}

As we sought to understand our identities as a generalist and specialist, we saw how, at this point in our careers in teacher education, they have become interwoven. Experience understood through situation, continuity, and interaction (Dewey, 1938) informed this interwoven aspect of our knowing. At present, we are mathematics teacher educators working in a university setting, and teaching mathematics methods courses. It is in these situated classroom places that we understand our generalist and specialist practices as described in the last paragraph. And our teacher education practices are shaped by the stories we bring forward from our grade school classrooms and our experiences there alongside children, youth, and other colleagues.

Teachers develop a complex understanding of their children to support their work of curriculum construction in mathematics (Glanfield, 2003). Aoki (2005) wrote of the lived and planned curriculum as curricula that interact and demand negotiation of the teacher as the mediator of these two sites of knowing. It is in the middle of these two understandings of curriculum, the space between, where the work of the teacher is accomplished and identities are shaped. For Aoki, this is attending to multiplicity and he urges us to consider identity not as a noun or thing, but as "production, in the throes of being constituted as we live in a place of difference...identities... [and] ongoing effects of our becoming in difference” (p. 205).

Stories to live by (Connelly \& Clandinin, 1999) are shaped in the space between the curriculum as planned and the curriculum as lived (Aoki, 2005). This understanding of curriculum helped us to understand ourselves as curriculum planners (Connelly \& Clandinin, 
1988) in our mathematics teacher education work. We use this understanding in relation to the planned curriculum of mathematics and the lived curriculum in the mathematics classroom with diverse learners. Curriculum is a complex concept. We do not say this lightly or as a way to avoid further engagement. Historically, we both viewed curriculum as that which was given to us by the government and expected to teach. Shifts in our understanding made curriculum more complex and this complexity made curriculum more real. Identity can reside in content or noncontent areas of curriculum. What, however, is content? We consider content to be the noun that can be separated from the doing of curriculum. Therefore, we can see ourselves in the content of mathematics or in the making of curriculum. Sometimes this noun is evident in the teaching; it exists prior to the teaching and is the intent of a pedagogical moment. At other times it is only by reflecting on the moment that the content is discernable.

Making and living curriculum is a dynamic and complex process. This means that it is always unfolding. Understanding Aoki (2005) means, for us, knowing curriculum as a tension between what needs to be covered and what needs to be understood pedagogically. This exists at the level of the elementary and secondary teacher as they endeavour to cover the mandated, planned mathematics curriculum, while living with the tension that all children will not respond to this curriculum in the same manner. At the post secondary level, we both create course outlines that can be considered the curriculum of the university students in our classroom. These outlines attend to the ideas that shape our planned curriculum. To do this we feel we need to cover the subject matter content that the preservice teachers will be expected to teach in their practice. We also feel we need to provide examples and opportunities to introduce and have preservice teachers come to know a variety of instructional and assessment strategies. Further, we are bombarded by the literature that suggests we need to address preservice teacher beliefs about mathematics education. For us this is the intended curriculum based on the pressures we feel within our teacher education programme.

Curriculum in our mathematics education classes is shaped by our students' experience of our planned curriculum. It also means that our students shape our experience of the planned curriculum. We both attend to the developing narratives of our students. For us, these are their stories to live by as mathematics educators. It is in the attention to this lived curriculum that we saw the limitations of generalist and specialist identities.

\section{Neither Specialist Nor Generalist: Learning Alongside Preservice Teachers}

We came to see that we were no longer specialists or generalists. As we reconsider our narratives, we wonder if these constructs were ever wholly definitive of our work in classrooms. Shaun saw the complexity and movement back and forth between being a generalist and a specialist as beginning in his understanding of life in an elementary classroom. He recognized the fluid nature of shaping curriculum with elementary children as they work across subjects and weave ideas together. For him, an understanding of his work as both a specialist and generalist is central in his work with preservice teachers. Each of his classes at university begins with a piece of children's literature. He does this in order for the preservice teachers to see how we need mathematics in order to understand experience and we cannot talk about a text without reverting to mathematics. He invites them to consider how other subject matters can be integrated into mathematics teaching. He structures the rhythm of his class as he would an elementary classroom in order for preservice teachers to develop an understanding of the rhythms of teaching elementary children. There is a strong focus on the pedagogy of mathematics education. Woven through this is the content of mathematics for elementary schools. The pedagogy 
becomes the scaffold for the content and the content is essential as it gives him and his students their curricular purpose. Relationship is central in this understanding-relationships among teachers and children, teachers and subject matter, among discrete subject matters, and relationships among mathematics concepts-as he builds a content structure over the term that addresses the different mathematical ideas in relation to each other.

Florence attends to the developing narratives of her preservice teachers as mathematics educators from her understanding of mathematics. For Florence's classes preservice teachers', narratives develop within the fluidity of mathematics itself by explorations of the way in which mathematical content is developed throughout the provincial curriculum. Florence begins her classes with a question or questions that focus the exploration for the day or the week. The questions are about the relationships among mathematical content-content that many preservice teachers see as discrete, but content that Florence sees as continuous. The content is the focus, and woven through the exploration of the content is the pedagogy. For example, one question that may lead a discussion is "What is the relationship or are the relationships between addition, subtraction, multiplication and division of whole numbers?" This question leads to the exploration of the ways in which we teach about arithmetic operations from Pre K-Grade 6; the multiple representations that can be used to teach children about those ideas; the role of both teacher language and child language in coming to understand the arithmetic operations; the way in which teachers can assess children's understanding of the operations at particular grade levels; and the activities used for the preservice teachers to explore their own understanding of the mathematical ideas.

As we create our course outlines and lesson plans, we shape the curriculum as planned. In the life of our preservice classrooms, this planned curriculum is lived out as all of the curriculum commonplaces interact. However, we have come to understand that it is the space between these two, planning and living, that we know our identities as mathematics teacher educators.

\section{Final Thoughts}

Tensions of identity, content, pedagogy, and curriculum making shape our practice in mathematics teacher education, not the constructs of generalist or specialist. For us curriculum making is about negotiating the tensions among content, pedagogy, and identity. We have said little about tension, but this paper and research interest arose of the tensions we felt in our teacher education work. Often we are asked to name ourselves as specialists in a subject matter in mathematics teacher education. One of the tensions we experienced is that we are more than just mathematics educators; we are teacher educators. Colleges and faculties of education are often heavily slanted in curriculum departments to specialized subject area knowledge. Our experience, however, in teacher education, is that if we focus solely on subject matter we miss the opportunity to develop a more responsive teacher education classroom that attends to the future complexities that preservice teachers will encounter in their professional lives. Tension in this way might be seen as something with a negative valence (Clandinin, Murphy, Huber, \& Murray Orr, 2009), however, we have been able to see the educative possibilities for ourselves and furthermore understand that tensions in our stories to live by have shaped our teaching practices in positive ways.

By researching our stories to live by as a generalist and specialist we have come to see that these are not defining constructs for our work as grade school teachers or as mathematics teacher educators. In fact we have come to see that these constructs are limiting. As we unpacked 
our narratives, we came to see how we story ourselves as teachers with shifting knowledge in subject matters that has always been attentive to the people we teach.

Our teacher education classrooms have become sites of curriculum making as they filter knowledge and express it. "To act is to theorize," wrote Joanne Pagano (1991), and for us, this is one way we understand our work with preservice teachers and encourage them to use as a way of understanding their practice. It invites all of us into a practice-theory relationship and allows for a way of negotiating the tensions of curriculum making in an integrated manner that attends to subject matter, the historical nature of our stories to live by in relation to mathematics, pedagogical concerns, and the classrooms we construct.

Conversation has been essential in this paper and is a necessary part of our mathematics teacher education classes. We see the conversation (Glanfield et al., 2006) as a way we shape our identities as mathematics teacher educators. At the core of our wonders around specialist and generalist constructions is the understanding that teacher identity is foundational. In mathematics teacher education, this bears consideration because it is not just about content, but teacher identity creation. The curriculum commonplaces of learner, teacher, subject matter, and milieu (Schwab, 1978) shape our understanding of curriculum making. Subject matter is no more important in this theory of curriculum than the other commonplaces. If, as mathematics teacher educators, we privilege content over pedagogy, if we place our knowing over the knowing of the learner, then we are not engaged in curriculum making and we end up limiting the practice of future teachers. We would like to suggest that the unifying force among the commonplaces of curriculum is the identities we bring to our work as curriculum makers.

An interest in mathematics education transcends our specialist and generalist identities and brings us together in community. A curiosity about mathematics is an obligation of the teacher of mathematics (Simmt, Davis, Gordon, \& Towers, 2003). For us, curiosity about mathematics is an aspect of our identity as teacher educators. We hold other curiosities in areas of identity, pedagogy, and curriculum. These curiosities are integral to our practice as mathematics teacher educators. Teacher educators and preservice teachers require an identity related to a subject matter in order to engage with that subject matter. In this way we stepped away from the restraints of generalist and specialist and begin to understand our teaching in more complex ways. Attention to both, to a deep understanding of subject matter, and to children, youth, and adults across subject matters and their lives, transcends ideas of being a generalist and specialist in grade schools and in teacher education. 


\section{References}

Aoki, T. T. (2005). Legitimating lived curriculum: Toward a curricular landscape of multiplicity. In W. Pinar \& R. L. Irwin (Eds.), Curriculum in a new key: The collected works of Ted T. Aoki (pp. 199-215). Mahwah, N.J.: Lawrence Erlbaum Associates Publishers.

Clandinin, D. J., \& Connelly, F. M. (1992). Teacher as curriculum maker. In P. W. Jackson (Ed.), Handbook of research on curriculum (pp. 363-401). New York: Macmillan.

Clandinin, D. J., \& Connelly, F. M. (1995). Teachers' professional knowledge landscapes. New York: Teachers College Press.

Clandinin, D. J., \& Connelly, F. M. (1996). Teachers' professional knowledge landscapes: Teacher stories-Stories of teachers-School stories-Stories of schools. Educational Researcher, 25(3), 24-30.

Clandinin, D. J., \& Connelly, F. M. (2000). Narrative inquiry: Experience and story in qualitative research. San Francisco, Calif.: Jossey-Bass.

Clandinin, D. J., Murphy, M. S., Huber, J., \& Murray Orr, A. (2009). Negotiating narrative inquiries: Living in a tension-filled midst. Journal of Educational Research, 103(2), 81-90.

Connelly, F. M., \& Clandinin, D. J. (1988). Teachers as curriculum planners: Narratives of experience. New York: Teachers College Press.

Connelly, F. M., \& Clandinin, D. J. (1999). Shaping a professional identity: Stories of educational practice. New York: Teachers College Press.

Connelly, F. M., \& Clandinin, D. J. (2006). Narrative Inquiry. In J. Green, G. Camilli \& P. Elmore (Eds.), Handbook of complementary methods in education research (pp. 477-487). Mahwah, NJ: Lawrence Erlbaum.

Davis, B., Sumara, D. J., \& Luce-Kapler, R. (2000). Engaging minds: Learning and teaching in a complex world. Mahwah, N.J.: L. Erlbaum Associates.

Dewey, J. (1938). Experience and education. New York: Simon and Schuster Inc.

Dewey, J. (1997). Democracy and education: An introduction to the philosophy of education. New York: Free Press.

Glanfield, F. (2003). Mathematics teacher understanding as an emergent phenomenon. Unpublished doctoral dissertation, University of Alberta, Edmonton, AB.

Glanfield, F., Oviatt, A., \& Bazcuk, D. (2006). From teachers' conversations to students' mathematical communications. In L. R. Van Zoest (Ed.), Teachers engaged in research: Inquiry into mathematics classrooms, Grades 9-12 (pp. 75-96). Greenwich, CT: Information Age Publishing.

Murphy, M. S. (2004). Understanding children's knowledge: A narrative inquiry into school experiences. Unpublished Dissertation/Thesis, University of Alberta, Edmonton, AB.

Murphy, M. S. (2007, April). Stories in relationship: Experience, identity, and epistemology in an elementary classroom. Paper presented at the American Educational Research Association. Chicago, Illinois. 
Pagano, J. A. (1991). Moral fictions: The dilemma of theory and practice. In C. Witherell \& N. Noddings (Eds.), Stories lives tell: Narrative and dialogue in education. New York: Teachers College Press.

Schwab, J. J. (1978). The practical: Translation into curriculum. In I. Westbury \& N. J. Wilkof (Eds.), Science, curriculum, and liberal education: Selected essays (pp. 365-383). Chicago: University of Chicago Press.

Simmt, E., Davis, B., Gordon, L., \& Towers, J. (2003, July). Teachers' mathematics: Curious obligations. Paper presented at the Joint meeting of the International group for the Psychology of Mathematics Education and Psychology of Mathematics Education North America Chapter, Honolulu, HI 